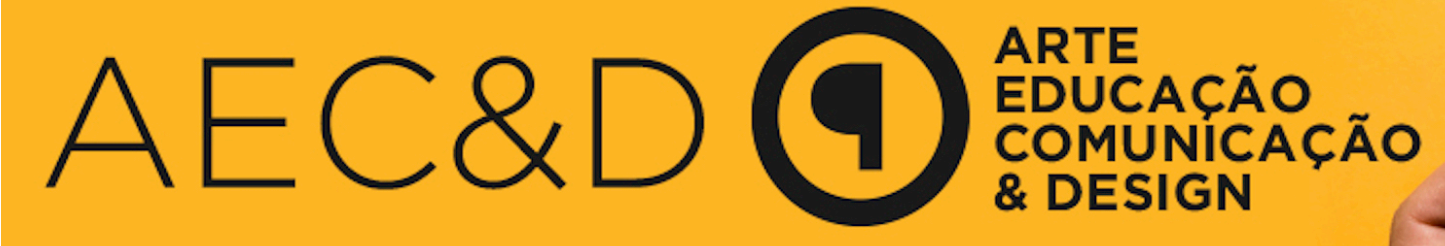

\title{
SUÍTE AMAZÔNIDA: COMPOSIÇÃO DE UM ARRANJO CORAL SOBRE DUAS TOADAS DE BOI-BUMBÁ
}

Suite amazónica: composición de un arreglo coral teniendo en cuenta dos canciones de "boi-bumbá"

\author{
Lima, Lucas ${ }^{1}$, Gomes, Hermes² \\ ${ }^{1}$ Secretaria de Estado de Educação e Qualidade do Ensino- lucaasmesquitaa@gmail.com \\ ${ }^{2}$ Universidade Federal do Amazonas- hermescoelho@gmail.com
}

Resumo: No âmbito da criação musical, variadas são as alternativas disponíveis ao que se propõe à missão de adentrar neste processo. Dentre as múltiplas ferramentas inerentes à realização de tal tarefa, pode haver, por vezes, ambiguidade de significações em termos como a composição, arranjo e transcrição musical. Ao elucidar a diferença e compreender como tais técnicas podem se relacionar, propõese, aqui, a elaboração de um arranjo composicional, para coral a quatro vozes, a partir de duas toadas do Boi-Bumbá de Parintins, sendo estas: "Amazonas Meu Amor" e "Rio Amazonas", bem como a realização de uma análise musical descritiva e minuciosa acerca do arranjo construído, apontando as técnicas nele utilizadas e descrevendo as escolhas tomadas no processo composicional da obra, desde seu planejamento até sua conclusão.

Descritores: Arranjo Composicional; Toada de Boi-Bumbá; Análise Musical; Música Coral.

ABSTRACT: In the scope of musical creation, there are several alternatives available to those who propose to the mission of entering this process. Among the multiple tools that are inherent to the accomplishment of such a task, there can, sometimes, ambiguity of meanings in terms as composition, arrangement and musical transcription. By elucidating the difference and understanding how these techniques can relate, it is proposed, here, the elaboration of a compositional arrangement, for four-voice choir, from two tunes of the Boi-Bumbá de Parintins, being these: "Amazonas Meu Amor "and" Amazonas River", as well as conducting a descriptive and detailed musical analysis about the arrangement built, pointing out the techniques used in it and describing the choices made in the compositional process of the work, from its planning to its completion.

Descriptors: Compositional Arrangement; Toada de Boi-Bumbá; Musical Analysis; Choral music. 


\section{INTRODUÇ̃̃o}

"Suite Amazônida" é fruto de um trabalho que pode ser compreendido como um arranjo composicional. De fato, a partir do ponto de vista de alguns autores, pode parecer redundante o termo "composicional" agregado à palavra "arranjo". No entanto, de acordo com o pensamento de outros autores, há certa ambiguidade de significação inerente a "arranjo" como aponta Pereira (2011, p. 176) alegando que "o termo arranjo possui dois procedimentos distintos, um para a música erudita e outro para a música popular." Aragão complementa explicando:

[...] No universo clássico arranjo seria "a reelaboração de uma composição musical, normalmente para um meio diferente do original", enquanto no universo popular teríamos "a reelaboração ou recomposição de uma obra musical ou de parte dela (como a melodia) para um meio ou conjunto diferente do original". Ora, temos aí conceitos relativamente parecidos. Aparentemente, a diferença maior estaria na inclusão, no arranjo popular, do processo de "recomposição" alternado ou somado ao de "reelaboração", encontrado em ambos os verbetes, além da possibilidade de serem utilizados no arranjo popular apenas alguns elementos do original, enquanto o arranjo clássico lidaria com o arranjo na íntegra, (Aragão, apud Medeiros, 2009, p. 33).

A partir desta perspectiva, pode ser percebida grande semelhança entre a forma que a palavra arranjo é entendida no universo da "música clássica" com o do próprio significado do termo "transcrição", ao que o autor Alfred Blater nos ajuda a elucidar os significados de ambas:

Com o propósito de organização do material, uma distinção deve ser feita entre transcrição e arranjo. $O$ processo de transcrição é mais elementar: pegar uma composição escrita em um meio e reescrevê-la praticamente nota por nota, em outro meio. As alterações somente serão feitas se houver necessidade por diferenças idiomáticas entre os dois meios. $O$ arranjo é um processo que incorpora a transcrição e certa dose de composição. 0 processo de arranjo começa com algum material musical, talvez uma melodia e alguns acordes rudimentares e procede criando uma variedade de meios como escrevendo uma introdução e um final, construindo passagens de transição, adicionando contrapontos, criando linha do baixo, adicionando ornamentos na melodia e elaborando uma estrutura harmônica. (BLATER, 1980, p. 256).

Seguindo esta linha de pensamento, conclui-se que, no que se compreende no âmbito do arranjo, é "permitido modificar, acrescentar diminuir, enfim, adquirir maior flexibilidade de manipulação de elementos estruturais" em uma obra. (PEREIRA, 2011, p. 176).

Para Almada (2000, p. 17) o estudo e o trabalho tanto do arranjo quanto da composição estão intimamente ligados pelos conteúdos que os permeiam, sendo estes, matérias teóricas fundamentais para o real entendimento musical como: o contraponto, a harmonia, a morfologia e a instrumentação, acrescidos ainda "[...] do permanente objetivo, que todo músico deve ter, de aprimorar seu ouvido até níveis cada vez mais avançados de percepção.".

Desta forma, Suíte Amazônida une as obras de Chico da Silva e Emerson Maia, respectivamente "Amazonas meu amor" e "Rio Amazonas", em uma única obra aplicando diversas técnicas de arranjo e composição direcionadas a escrita de um arranjo para coral à quatro vozes, não sendo este um estilo 
de arranjo que consiste em apenas realizar uma simples harmonização de outras vozes sobre uma melodia, mas sim em um trabalho realmente composicional partir de melodias já existentes.

\section{Metodologia}

Carlos Almada em sua obra intitulada Arranjo defende a posição de que o planejamento é um dos elementos mais importantes no processo de construção musical. "É muito difícil conceber-se um bom arranjo (ou composição) sem que todas as etapas - entre elas, a arquitetura de sua forma - sejam predeterminadas, após um planejamento consciente e minucioso." (ALMADA, 2000 p.71). Desta forma, a produção do arranjo e a composição deste trabalho como um todo seguiu o seguinte planejamento:

- Escolha das duas toadas a serem trabalhadas;

- Transcrição da linha melódica das toadas e definição da harmonia a ser utilizada;

- Produção de material musical para uso na composição do arranjo: criação de levadas; diferentes fraseados rítmicos e melódicos; variações motívicas; variações harmônicas e construção de texturas múltiplas;

- Escrita e desenvolvimento da primeira seção;

- Escrita e desenvolvimento da segunda seção;

- Escrita e desenvolvimento da terceira seção;

- Revisão e correção da partitura;

- Análise descritiva sobre a obra;

- Produção de textos de fundamento;

\section{ANÁLISE DA PARTITURA}

\subsection{INFORMAÇÕES PRELIMINARES}

Como já dito anteriormente, "Suíte Amazônida" trata-se da junção e elaboração de um arranjo coral a 4 vozes das músicas "Amazonas Meu Amor" e "Rio Amazonas". Sem fugir das raízes das composições que originaram este trabalho, esta é uma obra tonal, a qual tem seu início na tonalidade de F\#m, apresentando algumas variações e modulações pelo seu percursso musical.

O rítmo em si varia bastante na obra. Em seu decorrer é possivel observar certa alternância predominante entre compassos acéfalos e anacrústicos, deixando pouco espaço a compassos téticos, sendo estes utilizados poucas vezes e em geral como acompanhamento da melódia, ou em momentos nos quais se busca transmitir maior serenidade e/ou menor movimentação rítmica. Importante é ressaltar a presença da síncope, sendo esta figura predominante em praticamente todo o decorrer da obra.

A obra divide-se em 3 grandes partes a serem chamadas de seções, acrescidas, ainda, de introdução e coda. Salienta-se a presença de uma pequena coda ao fim de cada uma das duas primeiras seções, cabendo, assim, estas serem chamadas "codettas", de forma que possam ser diferidas em nomenclatura da grande e real coda ao fim da terceira e última seção da obra.

As seções A e B encarregam-se de apresentar, respectivamente, as duas canções precursoras deste trabalho: "Amazonas Meu Amor" e "Rio Amazonas", sendo cada música apresentada em uma seção 
diferente, atribuídas de um arranjo a 4 vozes bem elaborado. Já na seção $C$, busca-se a exploração de novas ideias com os materiais musicais das duas canções. Pode ser feita aqui, para esta seção, uma alusão a parte compreendia como "desenvolvimento" da forma sonata, na qual o compositor se utiliza de materiais previamente apresentados na "exposição", mas desenvolvendo-os além e de diferentes formas das anteriormente apresentadas, buscando novos caminhos rítmicos e melódicos, diferentes texturas sonoras, modulações, variações do que havia sido feito antes. Logo, as seções A e B podem ser analisadas como grandes temas 1 e 2 enquanto a terceira seção é o literal encontro e a culminância destes dois grandes temas onde serão desenvolvidos ao máximo de variadas formas.

Quanto a textura do sonora, a obra caracteriza-se em sua maior parte como polifônica, não deixando, no entanto, de apresentar partes em homofonia. Acerca disto, Almada (2000, p. 103) comenta: "Em uma composição, nada obriga ao emprego de apenas uma qualidade de textura. Ao contrário [...], a habilidade na utilização dos diferentes tipos de maneira contrastante é um dos mais eficientes recursos da criação artística.".

\subsection{ANÁLISE DeSCRITIVA}

\subsubsection{SEÇÃO A - C. 1 - 90}

\begin{tabular}{|c|c|c|c|c|c|} 
Seção A & Introdução & Período 1A (a) & Periodo 1A (b) & Periodo 2A (a) & Periodo 2A (b) \\
\hline c. $1-90$ & c. $1-18$ & c. $18-25$ & c. $26-33$ & c. $34-41$ & c. $42-49$
\end{tabular}

\begin{tabular}{|c|c|c|c|c|} 
Periodo 3A (a) & Periodo 3A (b) & Transição a & Codetta A(a) & Codetta A(b) \\
\hline c. $50-57$ & c. $58-65$ & c. $66-73$ & c. $75-82$ & c. $83-90$
\end{tabular}

Gráfico 1 Forma Seção A - Fonte: elaboração dos autores.

\section{Introdução - c.1 - 18}

A introdução constitui-se de um único motivo musical em ostinato durante 16 compassos que, assim, é compreendido em 4 frases de 4 compassos cada.

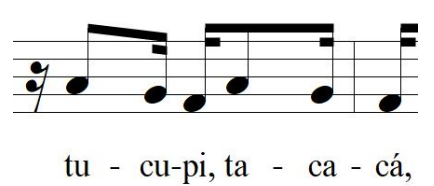

Figura 1 - motivo musical - Fonte: elaboração dos autores.

O naipe de contraltos é o primeiro a apresentar esta ideia musical completa, ao que, a cada repetição, uma nova voz é acrescida com uma diferente nota do acorde até que, por fim, se forme um acorde de F\#m no compasso 14.

A partir da entrada do naipe de sopranos (c. 9) uma harmonia modal é formada. Com a nota Re\# sendo cantada por este naipe, o modo dórico fica claro neste trechoda obra. Nos compassos 15 e 16, o naipe de tenores reafirma, ainda, a característica modal ao manter o Ré\# em sua linha melódica. 


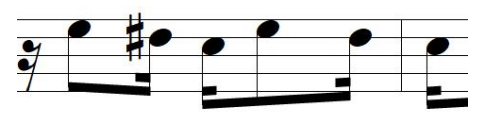

tu - cu-pi, ta - ca - cá,

Figura 2 - Compasso 9 - Soprano Fonte: elaboração dos autores.

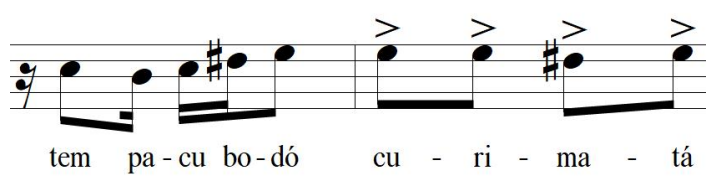

Figura 3 - Compasso 15 - Tenor Fonte: elaboração dos autores.

\section{Período $1 \mathrm{~A}$ - c.18 - 33}

Imediatamente após a introdução, há um compasso de súbito silêncio seguido de um acorde de C\#+ no acompanhamento instrumental, criando-se uma atmosfera de mistério e tensão a preparar a entrada da primeira seção da obra, onde a tensão anteriormente criada é resolvida sobre a tônica da música F\#m.

Neste primeiro momento a melodia é conduzida pelo naipes de baixos. Tendo sua entrada no compasso 19, é uma melodia anacrústica que logo no compasso seguinte passa a ser dobrada pelo naipe de tenores, gerando um diálogo entre as duas vozes. Há um breve cruzamento de vozes mas que logo é desfeito através da condução vocal pelo movimento contrário.

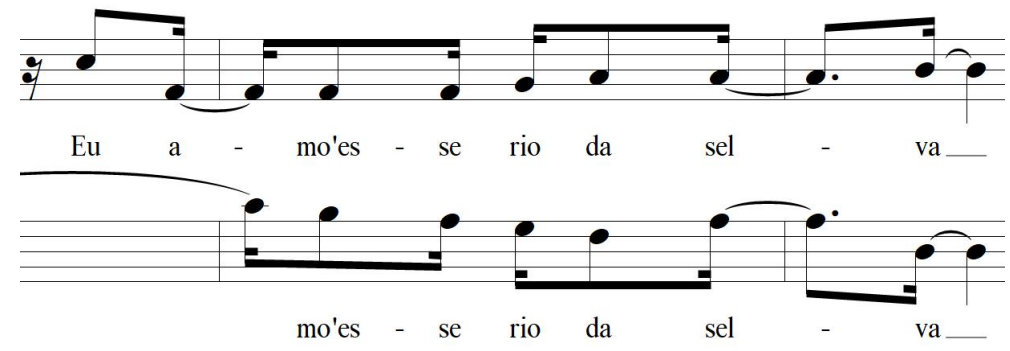

Figura 4 - Compasso 19 ao 21 - Tenor e Baixo - Fonte: elaboração dos autores.

No compasso 24, ainda em um movimento anacrústico, o tenor executa uma antecipação da melodia que viria a ser continuada logo no compasso seguinte pelo baixo. Na sequência ocorre a primeira entrada dos naipes femininos. Soprano e contralto entram no compasso 27 ao que logo o tenor se junta a elas, harmonizando o acorde de F\#m realizando assim uma melodia acompanhada. A partir do compasso 29 o tenor inicia um movimento contrapontístico de cromatismo descendente acompanhado pelo contralto, em movimento paralelo, no compasso posterior. Esta movimentação culmina em uma sucessão de acordes de função dominante, que, por sua vez, levam até o grau dominante da tonalidade, finalizando o primeiro período desta seção em uma cadêcia suspensiva.

Período 2A - c. $34-49$

O segundo periodo é iniciado com os naipes masculinos invertendo entre si seus papeis anteriores. $O$ tenor assume a melodia principal enquanto o baixo inicia com uma imitação e caminha em paralelo posteriormente juntando-se ao acompanhamento. Na sequência, baixo, contralto e soprano se juntam e fazem o acompanhamento em rítmo único, alternando entre movimento paralelo e contrário. No compasso 45, enquanto as vozes superioes repousam sobre o acorde de F\#m, o baixo movimenta-se individualmente em direção à tônica. A este tipo de recurso composicional damos o nome de 


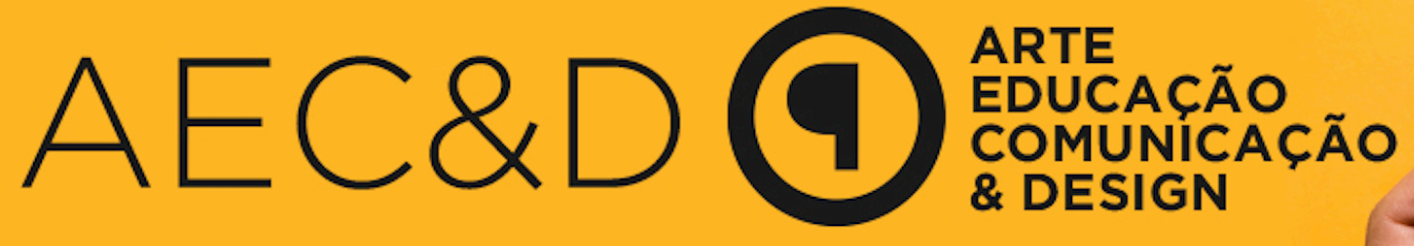

movimento obíqquo: "[...] no movimento oblíquo uma das vozes se sustenta enquanto a outra se move [...] não importando o intervalo usado." (ALMADA, 2000, p.132). O mesmo de repete no compasso 47, após um cromatismo descendente realizado pelos extremos graves. No entanto, desta vez o recurso é utilizado de forma inversa: enquanto o baixo repousa sobre a funtamental do VIo grau da tonalidade, as vozes superiores se movimentam harmonizando a melodia.

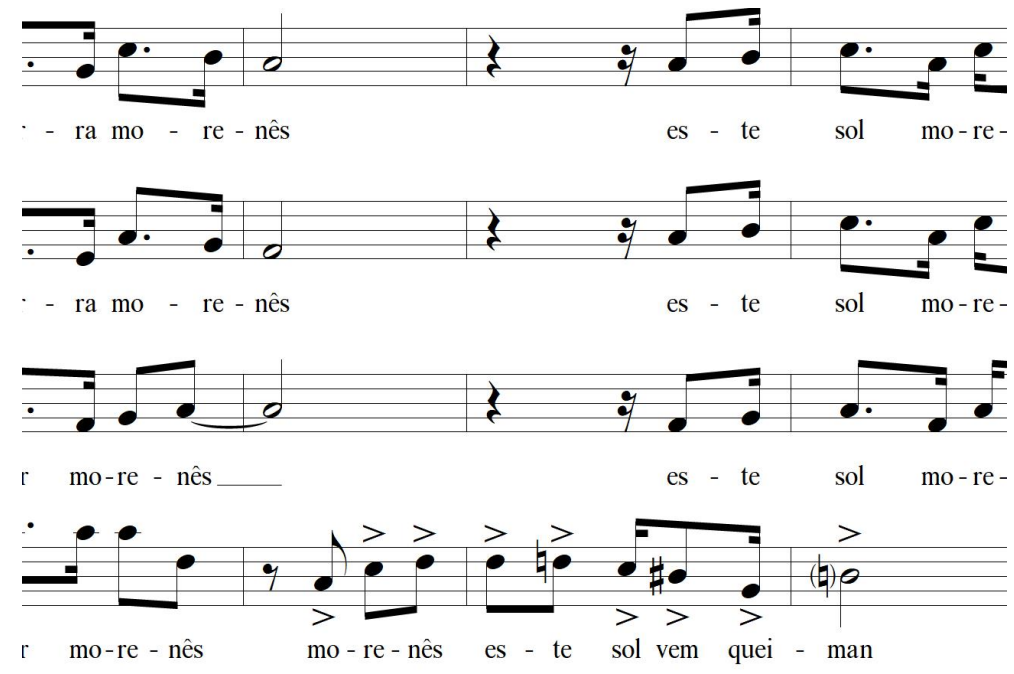

Figura 5 - Período 2A - Compasso 34 ao 49 - Fonte: elaboração dos autores.

Período 3A - c. 50-65

No compasso 50 ocorre o que podemos chamar de contracanto em paralelo a melodia principal. lan Guest (1996, p. 96) denomina o termo contracanto como simplesmente "[...] uma melodia que soa bem (que combina)" com outra melodia, ao que complementa afirmando: "A música organizada, quando a harmonia for bem conduzida [...] vários contracantos. Entre eles, o mais evidente é a linha do baixo da harmonia".

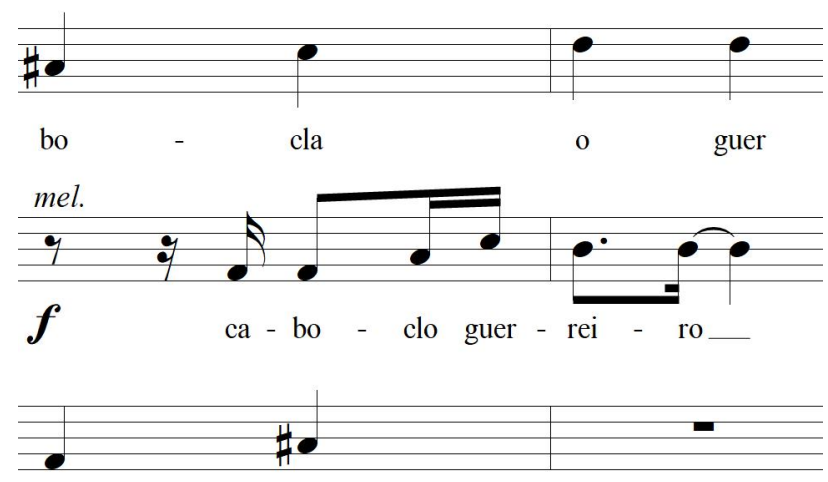

bo

cla

Figura 6 - Compasso 53 e 54 - Fonte: elaboração dos autores.

As duas linhas em questão melódicas são marcadas por "passearem" entre as 4 vozes do coral. A melodia principal inicia no baixo, passa para o contralto, é entregue ao tenor e concluída pelo soprano. É interessante atentar ao fato de que há uma ordem lógica quanto a distribuição de cada parte desta melodia pelos naipes entre os compassos 50 e 57. A letra da canção neste trecho traz os termos regionais cabocla, caboclo, cunhatã e curumim, os quais se referem, respectivamente, a figura da 
mulher, do homem, da menina e do menino amazonense. Assim sendo, observa-se uma relação direta do texto com as notas. As vozes graves (baixo e contralto) cantam a respeito do homem e da mulher adulta (o caboclo e a cabocla), enquanto as vozes agudas (soprano e tenor) trazem a figura da menina e do menino (a cunhatã e o curumim).

Quanto ao contracanto, trata-se de uma variação no texto da canção, harmonizada a duas vozes que também "passeia" entre os naipes. A harmonia neste trecho mostra-se como um encadeamento de cadências II-V-I. Após a reafirmação da tônica no compasso 50 , surge o acorde de $C \# m 7(b 5)$. Sendo este um acorde fora da tonalidade, pode ser compreendido como um II cadencial (II de Bm) por ser seguido de uma dominantização da tônica $F \#$, o que cria tensão e leva a música a resolvê-la sob o grau subdominante $\mathrm{Bm}$. O próprio $\mathrm{Bm}$, já no compasso seguinte, se torna segundo grau seguido de um E7 que leva o trecho ao tom relativo maior da tonalidade original da obra, A. Em seguida, surge novamente o acorde de G\#m7(b5) assumindo função subdominante como $\|^{\circ}$ grau cadencial, seguido da dominante C\#7, o que traz a música ao seu centro tonal original F\#m. Nos compassos 59 e 60, surge um contracanto realizado pelos naipes femininos que auxilia a preparar e potencializar a cadência ao fim do compasso 61.

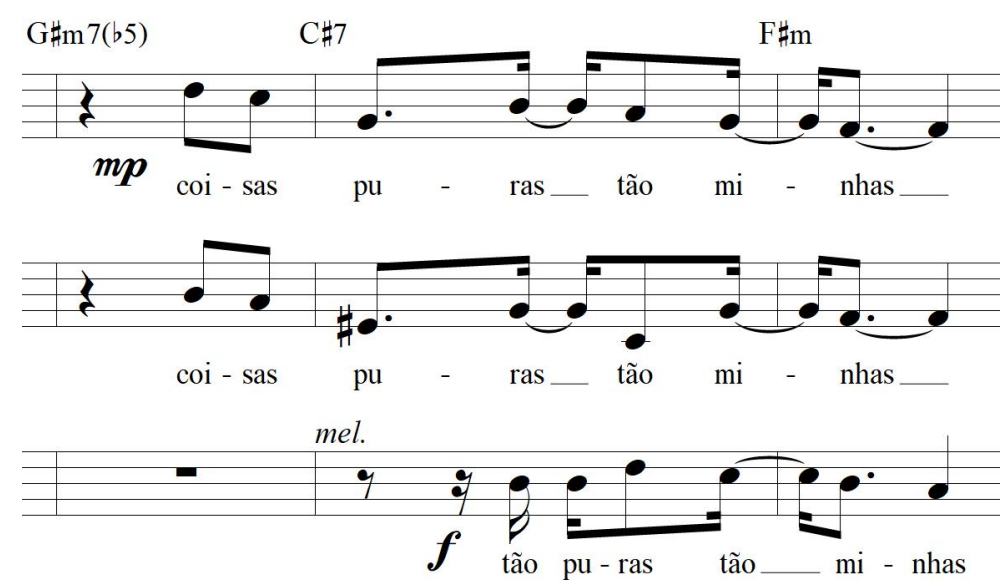

Figura 7 - Compasso 59 ao 61 - Fonte: elaboração dos autores.

O que ocorre no ultimo trecho análisado vem de encontro ao que lan Guest aborda em seu livro Harmonia Método Prático acerca das preparações dos graus pelo que chama preparação dominante: "Qualquer acorde maior ou menor pode ser precedido ou preparado por acorde dominante situado 5a J acima".(GUEST, 2006 p. 51) Ao que continua:

As tríades ou tétrades diatônicas podem representar um "descanso" ou resolução secundária chamado tom secundário desde que tenham 5aj em sua formação (acorde maior ou menor). $\mathrm{O}$ acorde do VII grau por não ter 5 a J não oferece estabilidade necessária para esse "descanso". Assim sendo, cada grau, exceto VII, pode ser preparado pelo dominante individual chamado dominante secundário. Este acorde estará situado 5å acima do acorde de resolução. No tom de dó maior, Dm7 é analisado IIm7 e pode ser preparado por A7 (que no tom secundário de ré menor funciona como V7). (GUEST, 2006, p. 52).

Após este trecho, tenor e baixo reassumem o protagonismo revezando entre si a voz principal, o que logo é interrompido ao compasso 63 com anacruze por algo que ecoa quase como um brado de guerra a ser entoado em unissono pelas quatro vozes. 


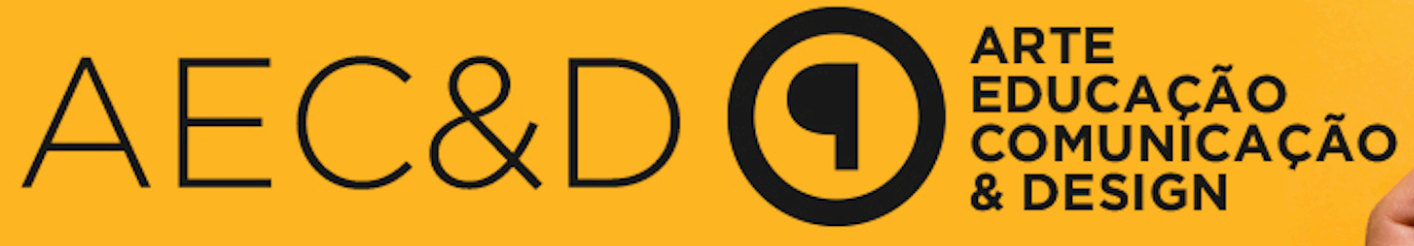

\section{Transição a - c. 66 - 73}

Imediatamente adiante, a frase compreendida entre os compassos 65 e 73 pode ser analisada como sendo uma pré-codetta, fazendo a ponte entre o terceiro período desta seção e sua pequena coda. 0 tenor inicía a frase e logo em seguida os demais naipes se juntam ao canto realizando o acompanhamento. O movimento cromático, assim como o movimento de arpejo realizado nos 4 primeiros compassos desta parte, fazem alusão direta a palavra "banzeiro", cantada pelo tenor, a qual refere-se as pequenas ondas formadas nos rios amazônicos. Ao mesmo tempo em que o, já referido, movimento de arpejo e a baixa movimentação rítmica buscam expressar em som o sentido da palavra "canção", apresentando um movimento mais melódico e tranquilo.

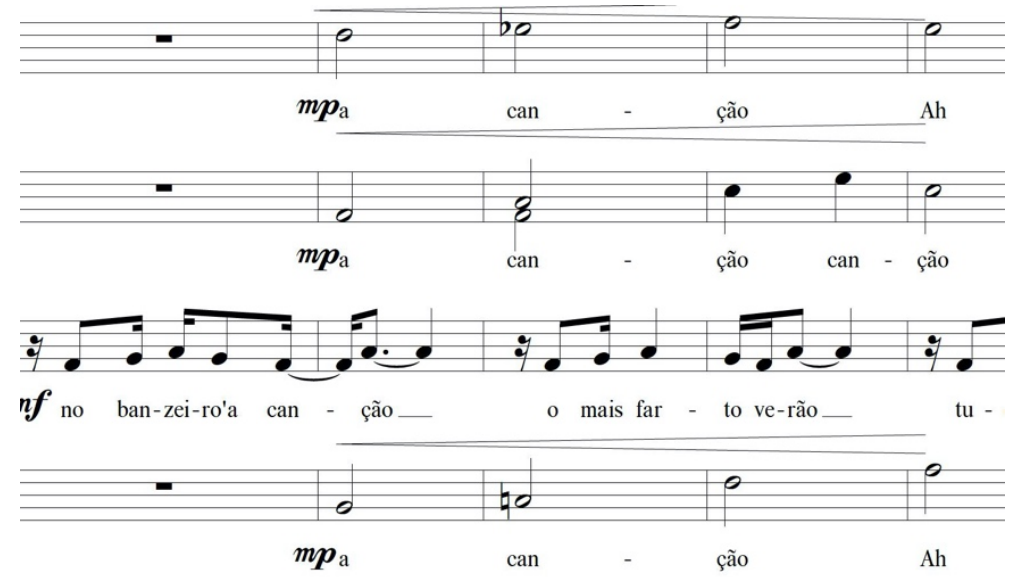

Figura 8 - Compasso 66 ao 70. - Fonte: elaboração dos autores.

A frase se encerra com a harmonia realizando novamente uma cadência II - V - I reafirmando da tonalidade da música, em um trecho onde as vozes intercalam suas entradas até finalmente se encontrarem formando o acorde de F\#m.

\section{Codetta A (a) - c. 75 - 82}

Segue-se então para a primeira frase da codetta, na qual um único motivo é apresentado pelo tenor e desenvolvido pelas demais vozes movimentando a harmonia.

Figura 9 - Compasso 75

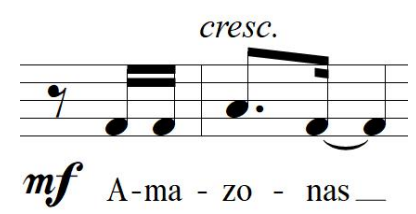

Fonte: elaboração dos autores.

\section{Codetta A (b) - c. 83 - 90}

A partir do compasso 83 com anacruze, tem-se a segunda frase da codetta, onde a frase original passa por variação, visando, assim, preparar o terreno para uma modulação. 0 soprano é quem puxa o motivo inicial desta vez, ao que as demais vozes agem em movimento paralelo, respondendo e movimentando a harmonia cromáticamente. Isto é desenvolvido até o ponto em que direcione a música ao acorde de E7, finalizando, assim, a primeira seção em uma cadência suspensiva indicando a nova tonalidade assumida a ser assumida: Am, tom homônimo do relativo maior de F\#m. 

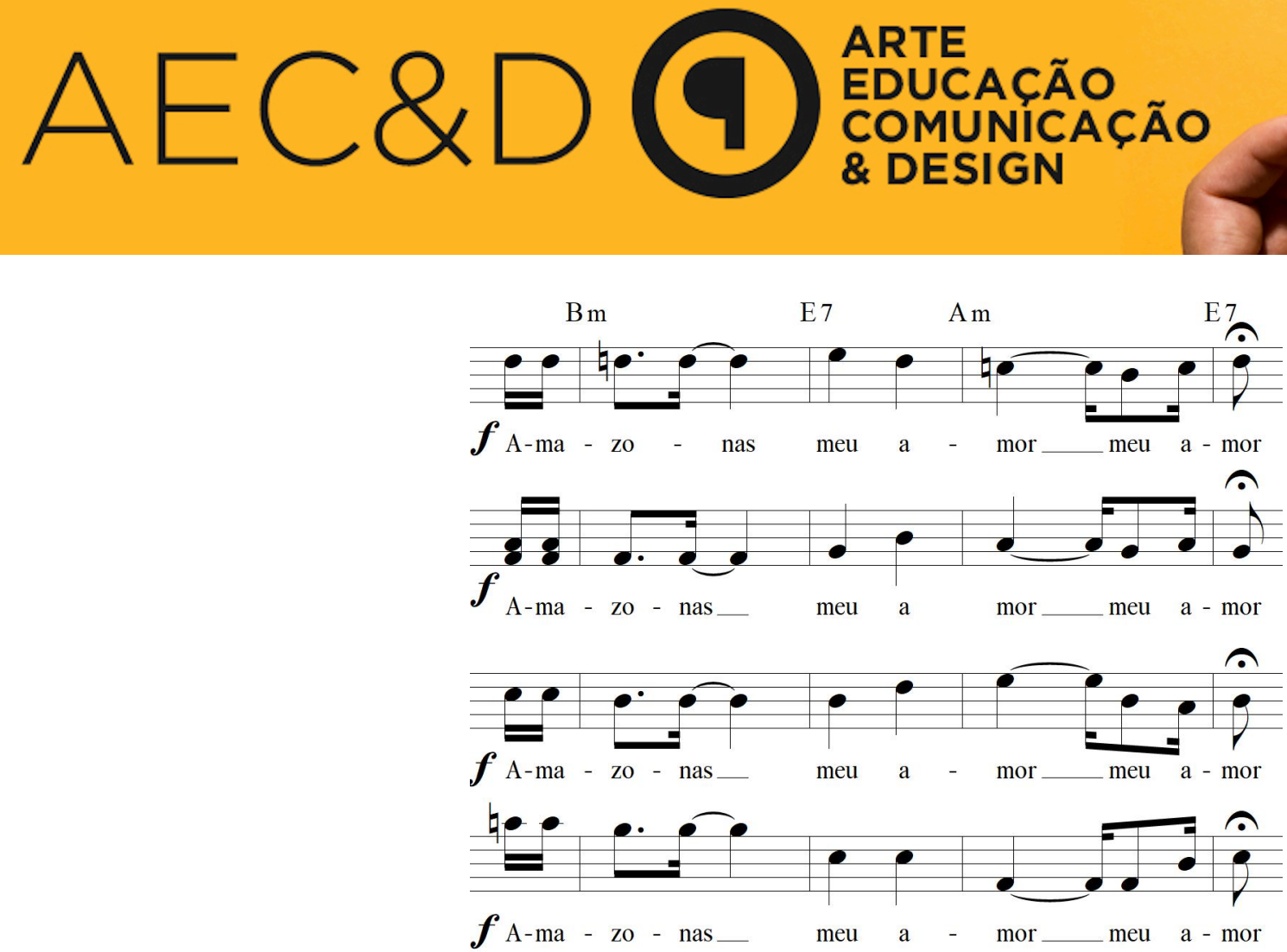

Figura 10 - Compasso 87 ao 90 - Fonte: elaboração dos autores.

\subsection{SEÇÃO B - C. $90-146$}

Nesta seção é exposta e desenvolvida a segunda canção geradora deste trabalho: "Rio Amazonas".

Enquanto na seção anterior os homens desempenham um papel de maior protagonismo, sendo responsáveis pela melodia principal em todo o percurso, a partir desta, tem-se um maior equilibrio no que diz respeito a distribuição da melodia entre as vozes.

\begin{tabular}{|c|c|c|c|c|} 
Seção B & Periodo 1B (a) & Período 1B (b) & Período 2B (a) & Período 2B (b) \\
\hline c. $90-146$ & c. $90-97$ & c. $98-105$ & c. $108-115$ & c. $116-123$ \\
$(57)$ & $(8)$ & $(8)$ & $(8)$ &
\end{tabular}

(8)

(8)

(8)

\begin{tabular}{|c|c|} 
Transição b & Codetta B \\
\hline c. $124-131$ & c. $131-146$
\end{tabular}

(8)

Gráfico 2 Forma Seção B - Fonte: elaboração dos autores.

\section{Período 1B - c. 90 - 105}

O naipe de contraltos inicía a melodia, expondo pela primeira vez a nova tonalidade. É importante observar a utilização de notas da escala de A menor melódica na primeira metade do incíso gerador da nova frase, o que se repete no compasso 94.

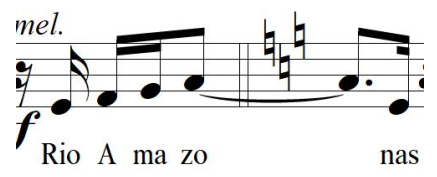

Figura 11 - Compasso 90 - Fonte: elaboração dos autores.

O soprano entra em seguida assumindo a melodia principal, enquanto o contralto passa a abrir a harmonia em movimento paralelo, finalizando, assim, a primeira frase em uma cadência suspensiva. 


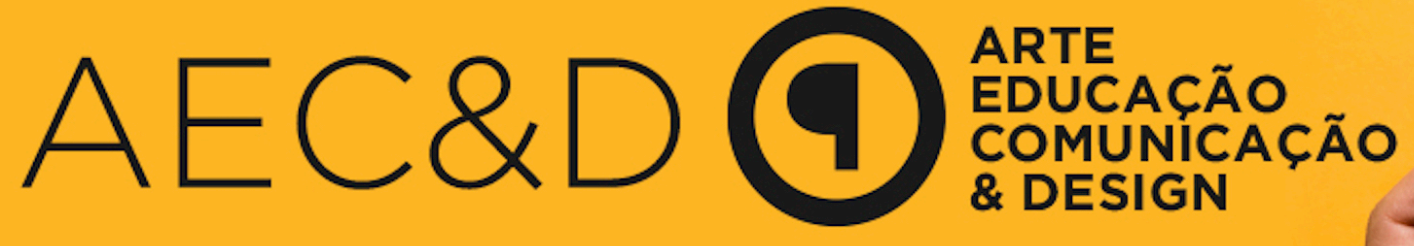

No compasso 99 volta a ser utilizada a técnica de melodia acompanhada (muito presente nesta seção). Os naipes masculinos fazem sua primeira entrada se unindo ao contralto formando toda a base harmônica para o soprano que mantém-se como voz principal.

No compasso de casa um, 105, baixo, tenor e contralto respondem à melodia principal, ao que tenor e contralto caminham em movimento paralelo enquanto o baixo realiza movimento contrário. Este trecho funciona de forma a reafirmar a tonalidade e realizar uma cadência suspensiva preparando a repetição.

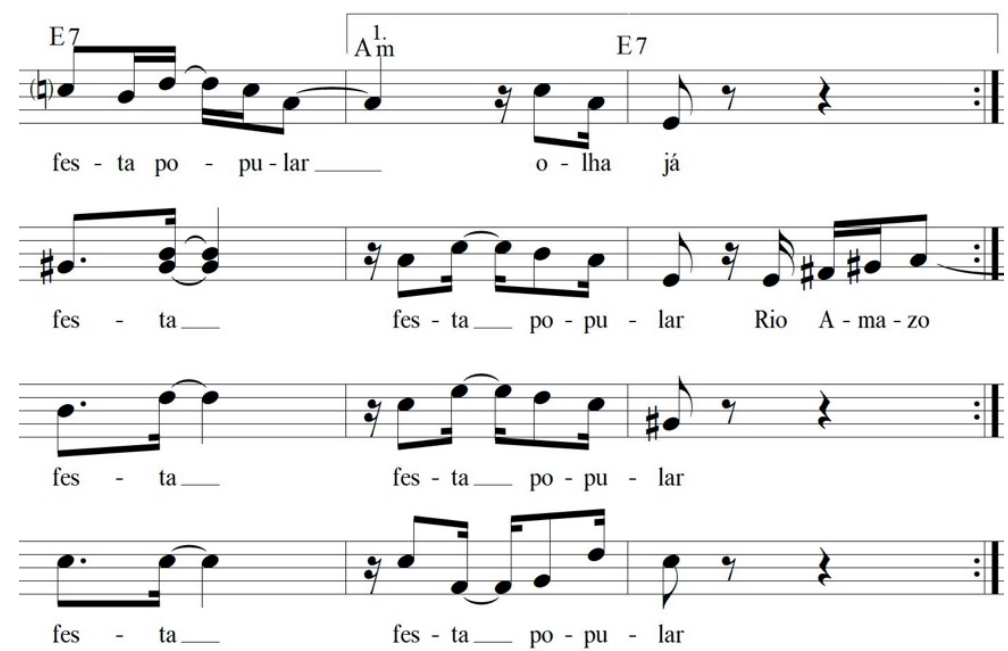

Figura 12 - Compasso 104 ao 106 Fonte: elaboração dos autores.

Na repetição surge uma variação a partir da linha do tenor que realiza um contracanto com pouca movimentação rítmica, caracterizando a isto um aspecto mais leve e melódico em contraste ao que está sendo apresentado na melodia principal. lan Guest denomina a este tipo de contracanto como contracanto passivo. "O contracanto passivo [...] tem o ritmo da própria harmonia: uma nota para cada acorde. É uma linha melódica que, além de funcionar "horizontalmente", usa notas que enriquecem bastante o som de cada acorde, portanto funcionando verticalmente." (GUEST, 1996, p. 97).

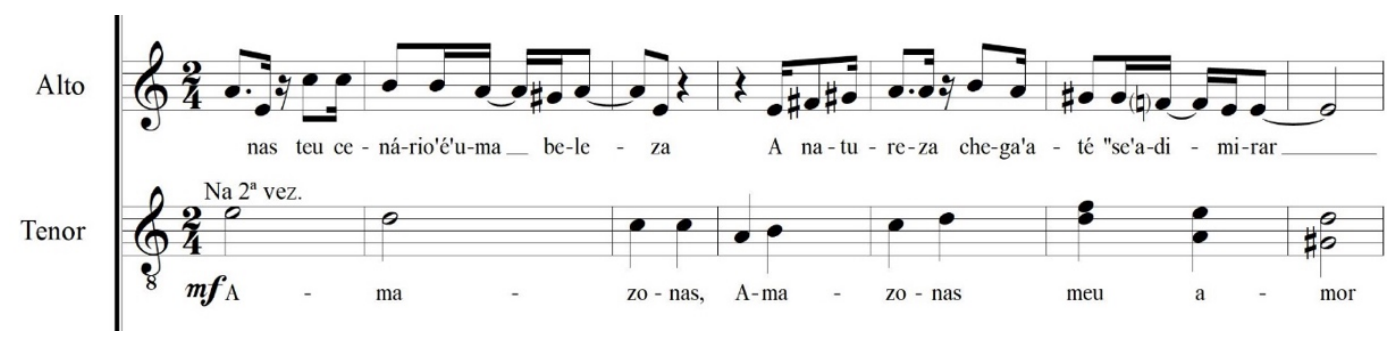

Figura 13 - Compasso 91 ao 97 - Fonte: elaboração dos autores.

Ao final da frase, partindo para o compasso de casa dois, observa-se os naipes que estão a realizar o acompanhamento melódico, mais uma vez, respondendo a melodia principal com uma variante do anteriormente feito, agora assegurando uma modulação ao tom homônimo da tonalidade: A maior. 


\section{AEC\&D ()}
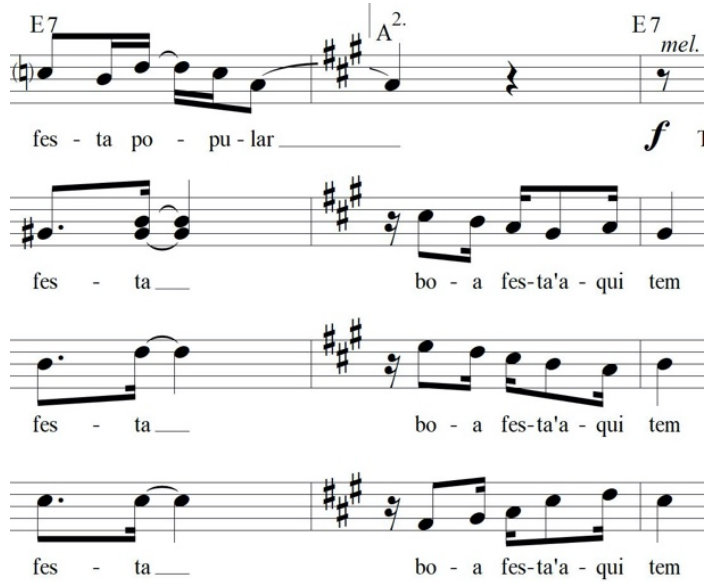

Figura 14 - Compasso 107 - Fonte: elaboração dos autores.

Periodo 2B - c. 108 - 123

A nova frase mantém as técnicas utilizadas na anterior sem grandes novidades com exceção da variação de tonalidade. O soprano traz a melodia a ser acompanhada pelas outras vozes que, por sua vez, mantém o movimento paralelo na harmonia. No compasso 116 , tenor assume a melodia com o contralto. Este segundo, por sua vez, já no compasso 117 abandona a melodia e junta-se ao acompanhamento com baixo e soprano. Neste mesmo compasso, podemos observar um movimento oblíquo no acompanhamento. Enquanto baixo e contralto sustentam as mesmas notas na harmonia, o naipe de sopranos realiza um cromatismo ascendente. A frase resolve-se em mais um compasso de transição que marca o retorno a tonalidade de $\mathrm{A}$ menor, novamente com o baixo realizando movimento contrário aos naipes superiores.

\section{Transição b - c. 124 - 131}

A partir do compasso 124 o tenor inicia uma melodia em ostinado formada por um único inciso que perdura por 6 compassos. Em movimento paralelo, o soprano intercala intervenções abrindo vozes sobre esta melodia, ao mesmo tempo em que contralto e baixo demarcam a harmonia movendo-se ascendentemente do $\mathrm{V}^{\circ}$ grau ao primeiro e tornando à dominante. Em seguida, soprano, contralto $\mathrm{e}$ baixo realizam um arpejo sobre $A$ menor, cada naipe sobre um diferente grau do acorde, ao que, na conclusão deste movimento, o acorde é dominantizado, sendo tranformado em A7 (movimento este a ser repetido no compasso 138 ).

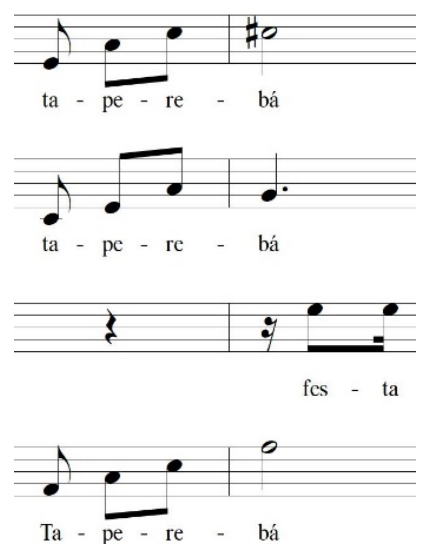

Figura 15 - Compasso 138 e 139 - Fonte: elaboração dos autores. 


\section{Codetta b - c. 131 - 146}

Este acorde prepara a entrada para a codetta desta seção, a qual consiste em uma frase de oito compassos que é repetida, sendo, na primeira vez, resolvida sob o acorde que representa a própria tonaldade vigente: Lá menor, e, na repetição, sofrendo variação em sua resolução, alterando a tonalidade a partir de então.

No compasso 132 podemos observar a existência de duas melodias sobrepostas. Uma apresentada pelas vozes intermediárias (contralto e tenor) e a outra pelas vozes das extremas (soprano e baixo).

$O$ tenor tem a primeira entrada e logo é seguido pelo contralto, os quais dobram a melodia abrindo vozes em terças inicialmente. Soprano e baixo também participam deste diálogo apresentando uma melodia a análoga a cantada pelos outros dois naipes. Este quadro é mantido até o compasso 137 (bem como na repetição c.145) onde soprano se junta às vozes intermediárias, deixando o baixo a fazer um caminho individual marcando as fundamentais dos acordes.

Após a repetição, o tenor, que antes resolvia sua frase sobre a tônica da tonalidade vigente (Am), agora resolve sobre a terça maior de Lá, finalizando, assim, a seção com o acorde de Lá maior sendo formado pelas quatro vozes, tom homônimo da tonalidade anterior.

\subsubsection{SEÇÃO C - C. $146-273$}

A terceira e ultima seção de "Suíte Amazônida" é predominantemente polifônica. Nesta procurou-se utilizar os materiais das duas seções anteriores desenvolvendo-os das maneiras mais elaboradas e diversificadas possíveis. (Gráfico 3)

\begin{tabular}{|c|c|c|c|c|} 
Seção C & Período 1B' & P. 1B" + P. 2A (b)' & P. 3A' + P. 3A" & P. 2B (a)' + Codetta B' \\
\hline c. $146-273$ & Período 1C & Período 2C & Período 3C & Periodo 4C \\
c. $146-161(16)$ & c. $162-177(16)$ & c. $178-194(16)$ & c. $194-210$
\end{tabular}

\begin{tabular}{l|c|c|c|} 
Período 3A"' & Transição a' & Codetta A(a)' + Codetta A(b)' & Coda \\
\hline Período 5C & c. $226-233$ & Pré-coda c. $234-249$ & c. $250-273$
\end{tabular}
c. $210-225$

Gráfico 3 Forma Seção C - Fonte: elaboração dos autores.

\section{Período 1C - c. 146 - 161}

O primeiro período desta seção consiste em uma variação do primeiro período da seção B. Antes em modo menor, o mesmo trecho é apresentado, agora pelo tenor, em modo maior na tonalidade de Lá. Nos dois compassos iniciais da seção podemos ver um movimento contrapontístico sendo relizado pelo soprano e contralto. O material musical apresentado por elas é uma variação e uma leve citação do primeiro inciso do período $1 \mathrm{~A}$ (a). Os dois naipes femininos seguem juntos por todo o período alternando sua movimentação em paralelo e oblíquo (com exceção dos compassos 152, 156 e 162, nos quais realizam movimento contrário). No compasso 150, o baixo faz sua entrada dobrando a melodia principal com o tenor. Nisto podemos observar a divisão das vozes em dois pólos distintos: masculino e feminino, estando cada pólo a apresentar um material diferente do outro.

No compasso 159 o baixo desvencilha-se do tenor, passando a realizar a tônica dos acordes que harmoniza com soprano e contralto. Os três naipes movimentam a harmonia conduzindo-a a uma 
dominantização do IIIㅇ grau da tonalidade vigente (A maior). Este movimento transforma o acorde de C\#m em C\#7 conferindo-Ihe função de "dominante secundário", o que é feito para levar a música a uma nova tonalidade. Desta forma, o período é finalizado sobre uma cadência suspensiva.

\section{Período 2C - c. 162 - 177}

Novamente apresentando o período $1 \mathrm{~B}$ (a) e de volta à voz do contralto, isto agora é feito sobre uma transposição à tonalidade relativa menor do tom homônimo de Lá menor (tonalidade na qual foi desenvolvida a seção B), levando a música a sua tonalidade inicial: F\#m.

$\mathrm{O}$ estilo contrapontístico acentua-se neste trecho. Em paralelo à melodia principal no contralto, cada naipe apresenta uma ideia musical diferente. Soprano e tenor ao fim do compasso 162 realizam uma antecipação do acorde que está por vir. Tenor inicía uma ideia e entrega ao baixo para que conclua no compasso seguinte, enquanto se junta à conclusão da frase iniciada pelo soprano.

No compasso 167 tenor inicía um contracanto que soa como um brado em meio as outras vozes, ao que o soprano junta-se à melodia com o contralto, e o baixo movimenta-se, de forma discreta, sobre as fundamentais dos acordes. O naipe de tenores finaliza o contracanto anteriormente anunciado realizando uma suspensão de quarta e resolvendo essa suspensão logo em seguida sobre a terça do acorde de C\#7. A harmonia não resolve imediatamente sobre a tônica após o acorde dominante, mas caminha diatonicamente, por grau conjunto, em sentido ascendente até a chegada em F\#m.

Neste caminho da harmonia, um episódio interessante surge. Enquanto o soprano, acompanhado do contralto, segue com o que seria a continuação da melodia do período $1 \mathrm{~B}$ - mais especificamente a primeira metade de $1 \mathrm{~B}$ (b) em variação - o tenor, por sua vez, acompanhado do baixo, surge, contrapontisticamente, com a melodia de 2A (b) em diminuição, caracterizando, portanto, uma variação nesta. As duas melodias caminham juntas paralelamente ao que no compasso 173 a primeira é interrompida, tornando a segunda o foco principal de todas as vozes. No compasso 173, assim como no 45, o baixo, indiviadualmente, realiza o mesmo caminho ascendente para chegar à tônica, logo após se direcionando, por cromatismo descendente, a repousar sobre o Vlo grau, enquanto as demais vozes tambem agem de forma semelhante como na primeira seção, porém com variação nas vozes femininas. Aqui, mais uma vez é feita uma tentativa de representar a palavra com a música. Enquanto os homens cantam a respeito do sol a queimar a própria tês, a mulheres dialogam com isto, em tom de lamento, no texto cantando "ai ai ai, minha tês". Observa-se que tanto o soprano quanto o contralto, no momento que antescede esta relação semiótica, vêm de um compasso inteiro de pausa, tendo acabado por finalizar sua ultima frase num registro grave. Na sequência direta, todas vozes entram em regiões medianas, com exceção do soprano que surge subitamente - do silêncio posterior de um Dó\#3 - em um Ré4, realizando, ainda, um intervalo de 5a diminuta descentende composta em sua melodia. Todas as vozes possuem características que aumentam a tensão pela forma que sua melodia é desenvolvida neste trecho. $O$ tenor executa um caminho advindo da escala menor melódica apresentando o VI e VII grau maiores em direção à tônica. O contralto, vindo da tônica, recai sobre a sensível da tonalidade e realiza um movimento paralelo ao soprano. $\mathrm{O}$ baixo, demarcando as fundamentais, executa dois movimentos cromáticos em pontos estratégicos de forma a potencializar as tensões em seu caminho à tônica, finalizando, assim, o período em cadência conclusíva.

Período 3C - c. 178 - 194

Este periodo é formado por duas variações do terceiro periodo da seção A. Na forma original, o trecho é desenvolvido sobre a tonalidade de F\#m. Aqui, é inicíado pelo acorde de E7 que anuncia a modulação 
ao tom relativo maior da tonalidade vigente. Desta forma, o período é desenvolvido na primeira vez em Lá maior e sua repetição no tom homônimo desta: Am.

Assim como na primeira seção, as melodias contrapostas se fazem presentes aqui.Tenor e contralto apresentam a melodia principal enquanto baixo e soprano interpoem o contracanto pertinente. Os compassos 183 e 184 se utilizam do mesmo material motívico da introdução na melodia principal.

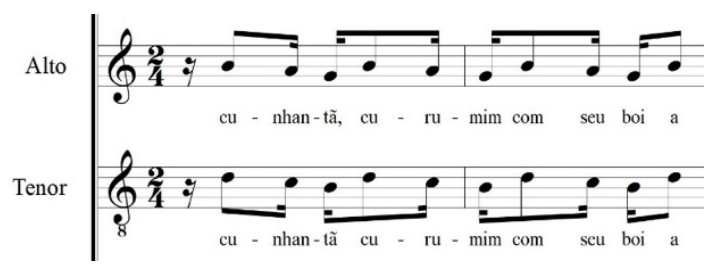

Figura 16 - Compasso 183 - Fonte: elaboração dos autores.

O compasso 185 é marcado pela homofonia nas vozes. As três vozes superioes movimentam-se paralelamente entre si enquanto o baixo realiza movimento contrário em relação a elas.

A frase segue pra sua variação no modo menor, ao que no compasso 191 ocorre ainda outra variação em rrelação à frase anterior. Baixo sustenta a dominante enquanto as vozes superiores executam as demais notas do acorde em arpejo que vem a soar como um tríade diminuta por conta da presença da 9a menor na extenção do acorde. Este acorde finda por resolver-se na própria dominante que direciona a música de volta a tonalidade de Lá maior assegurada pelo Dó\# cantado pelo tenor. No entanto esta resolução não se encerra nela mesma, uma vez que as vozes de imediato direcionam a harmonia à dominantiação de Dó\#, tornando novamente a ter F\#m como centro tonal.

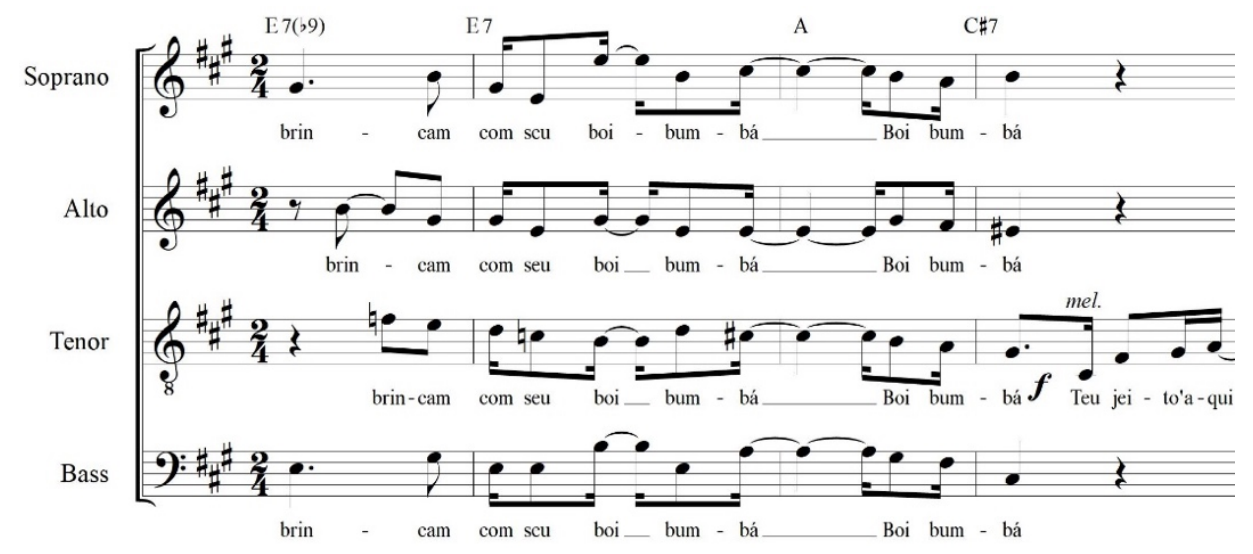

Figura 17 - Compasso 191 ao 194 - Fonte: elaboração dos autores.

Período 4C - c. $194-210$

Este período surge da variação do período $2 \mathrm{~B}$ (a) acrecido de outra variante de parte da codetta da seção B. $O$ trecho originalmente apresentado em modo maior, surge aqui em seu modo menor e ainda recebendo variação tímbrica sendo apresentado pelo naipe de tenores.

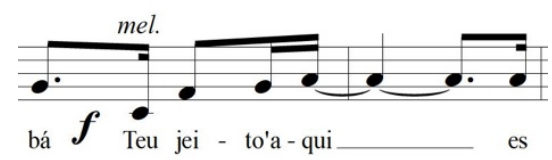

Figura 18 - Compasso 194 ao 195 - Fonte: elaboração dos autores. 
O baixo, em um caminho individual, traça uma linha melódica ascendente de baixa movimentação rítmica, até juntar-se brevemente com soprano e contralto, descendo por grau conjunto até a terça da dominante e realizando um pequeno salto de terça descentente para chegar à tônica da mesma. Os naipes femininos, por sua vez, estabelecem um contracanto por camadas, arpejando os acorde em movimento paralelo e acompanhando a linha do tenor. Tudo culmina na realização de mais um arpejo sobre um acorde diminuto no qual as vozes femininas intercam suas entradas e vozes masculinas entram juntas completando o acorde. Este ultimo acorde repousa a harmonia sob o grau subdominante $\mathrm{Bm}$ onde é retomado o tema da codetta $B$, aqui recebendo variação de tonalidade, timbre e forma. O soprano é responsavel pela melodia principal ao que é acompanhada pelas outras vozes que harmonizam o percurso até a chegada à dominante. No compasso 208 temos o baixo executando uma pequena célula musical como em anunciação do que vem pela frente.

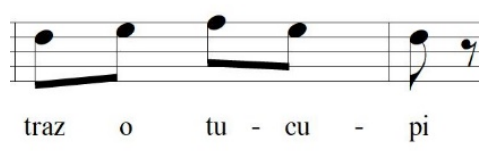

Figura 19 - Compasso 209 - Fonte: elaboração dos autores.

\section{Período 5C - c. $210-225$}

Este consiste em uma terceira variação mais elaborada do Período $3 \mathrm{~A}$ e com teor contrapontístico muito mais carregado. Aqui temos não apenas duas melodias contrapostas mas sim quatro vozes diferentes dialogando entre si.

O tema principal é alternado entre tenor e contralto a cada dois compassos. O baixo realiza uma melodia própria a qual dialoga com ainda um contracanto que também é alternado entre as vozes intermediárias (contralto e tenor). Observamos este sob a responsabilidade do tenor no compasso 211 , sendo passado ao contralto no compasso seguinte, tornando ao tenor no 214 , retomado pelo contralto em c. 216, sendo a ideia concluída pelo mesmo naipe em c. 218.

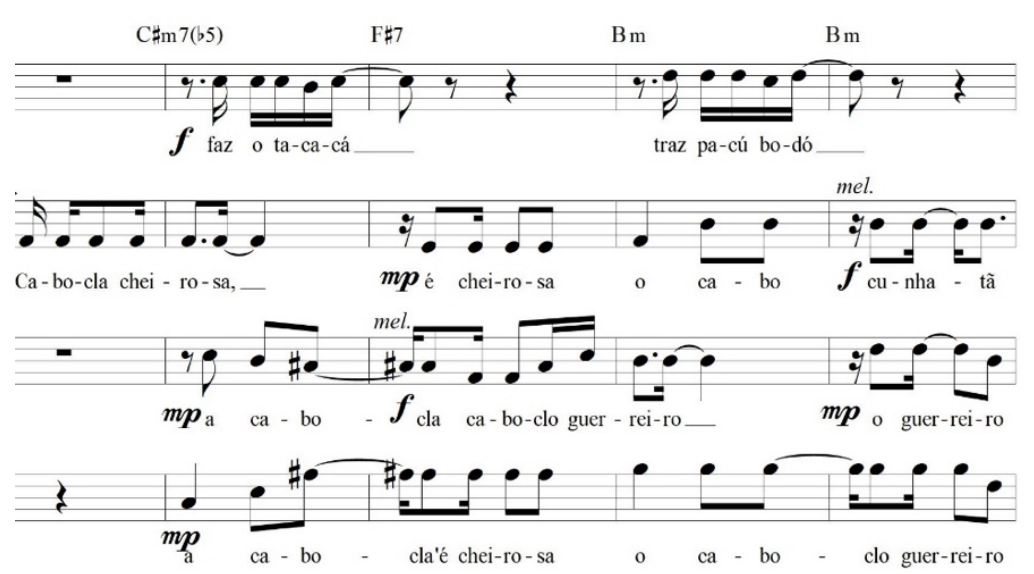

Figura 20 - Compasso 211 ao 214 - Fonte: elaboração dos autores.

Em parelelo a toda essa informação acontecendo simultaneamente, ainda temos a presença do soprano fazendo intervenções, em dialogo com a melodia principal se utilizando do material textual da frase de transição b (c. 124 -131) em citação à este mesmo trecho, finalizando a ideia que vinha trazendo se utilizando de aumentação no ultimo trecho (c. 217 -218). 


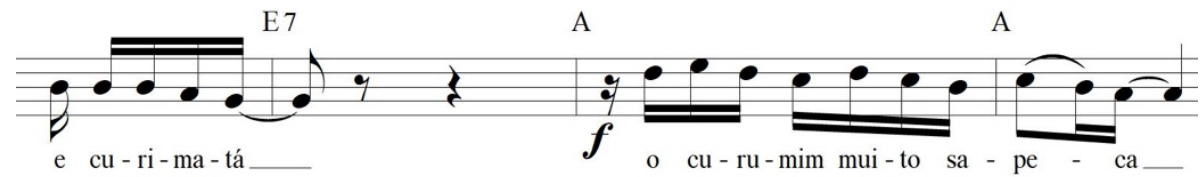

Figura 21 - Compasso 215 ao 218 - Fonte: elaboração dos autores.

A frase continua com tenor carregando a voz principal ao que as demais vozes acompanham se utilizando ainda de material textual da seção B. No compasso 219 os naipes femininos se movimentam em paralelo entre si mas obliquamente em relação ao baixo. No c. 221 e 222 todos os naipes bradam - alternadamente para que nenhum discurso musical se interrompa ou se atropele - em saltos de 5a $\mathbf{J}$ "Toada! Toada! Toada!" em tom de festa, ao que no c. 222 há indicação para um trecho "falado" ao tenor: "Olha a farinha!", em anunciação ao unissono dos compassos 223 ao 225.

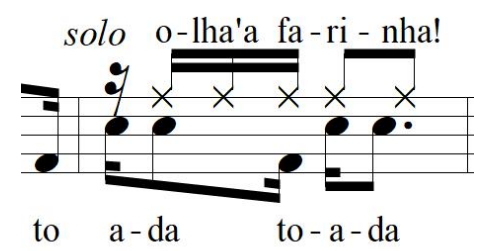

Figura 22 - Compasso 222 - Fonte: elaboração dos autores.

\section{Transição a' - c. 226 - 233}

A frase de transição presente da seção A repete-se, agora, com variações. Conduzida a melodia principal pelo contralto, percebe-se um empenho ainda maior em traduzir em som o significado das palavras. O "banzeiro" é bem representado pelo movimento harmônico escolhido - a presença do cromatismo na passagem de c. 227/228 valoriza isto), bem como pelas indicações de dinâmica e a forma arpejada em que as notas são reproduzidas. Tais escolhas fortalecem ainda mais a assimilação desejada, inclusive graficamente. A forma que as notas são dispostas na partitura remetém imediatamente a quem olha (nem que seja inconscientemente) à imagens de onda ou, ao menos, movimentos ondulatórios. O trecho seguinte busca o mesmo objetivo, agora com a palavra "canção", entoada pelas vozes do acompanhamento em pouca movimentação rítmica, de forma que valorize as vogais da palavra.

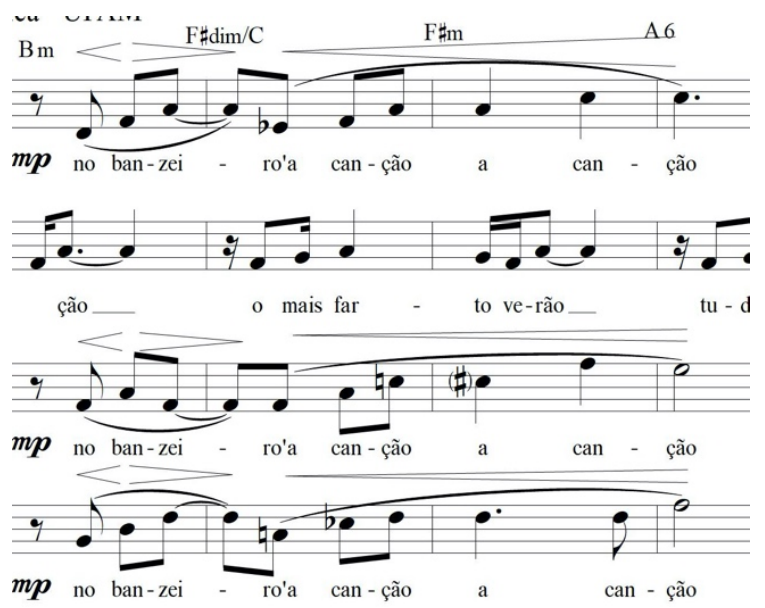

Figura 23 - Compasso 227 ao 230 - Fonte: elaboração dos autores. 


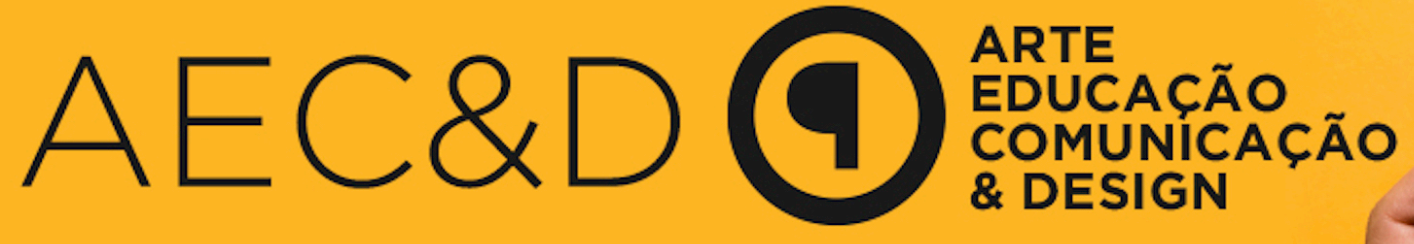

A frase é finalizada em uma simples cadência IV - V - I com o contralto realizando a escala menor melódica como escolha de aproximação à tônica.

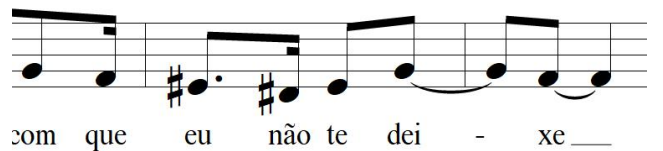

Figura 24 - Compasso 232 e 233 - Fonte: elaboração dos autores.

\section{Pré-coda c. 234 - 249}

Precedente à grande coda, este trecho constitui-se da própria codetta da seção A completa, com variações em ambas as suas partes, desta vez sendo finalizadas em cadência conclusiva. $O$ motivo sobre o qual é construída esta frase, incia-se pelo naipe dos baixos, passado ao contralto e, por fim, dobrado entre as vozes femininas. Enquanto isso, tenor e soprano dialogam paralelamente, em resposta a melódia principal nos compassos compreendidos entre 235 a 238. Ao entregar a melódia às contraltos, o baixo passa a demarcar as fundamentais dos acordes, passsando a ser acompanhado pelo tenor no compasso 239. Os naipes masculinos executam, ainda, um movimento de resposta à melodia principal no compasso 241.

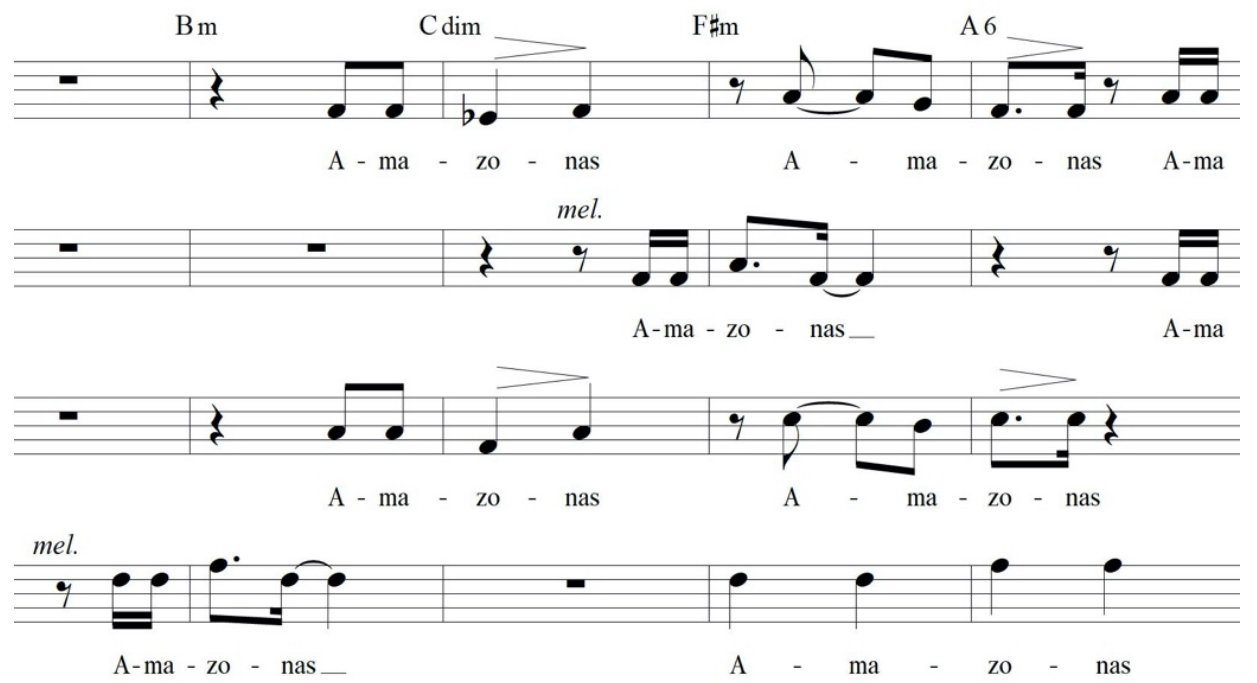

Figura 25 - Compasso 235 ao 238 - Fonte: elaboração dos autores.

Na continuação, temos o contralto iniciando a melodia com uma variação rítmica deslocando o apoio da célula músical, variação esta a ser reproduzidas por toda a frase. $O$ tenor realiza um contracanto passivo, em uma região relativamente aguda, conferindo-lhe um brilho especial. O tema principal é passado do contralto ao soprano e em seguida ao baixo. No compasso 245 , os naipes femininos agem em resposta ao baixo e assumem a melodia na sequência caminhando em movimento paralelo. No compasso 248 os homens marcam a cabeça do compasso com a finalização da frase ao que as mulheres respondem no contra-tempo e homofonicamente, finalizam a frase em uma cadência perfeita. 


\section{AEC\&D (9) \& DESIGN}

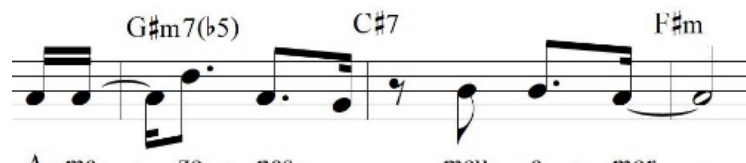

A - ma - zo - nas, __ meu a - mor
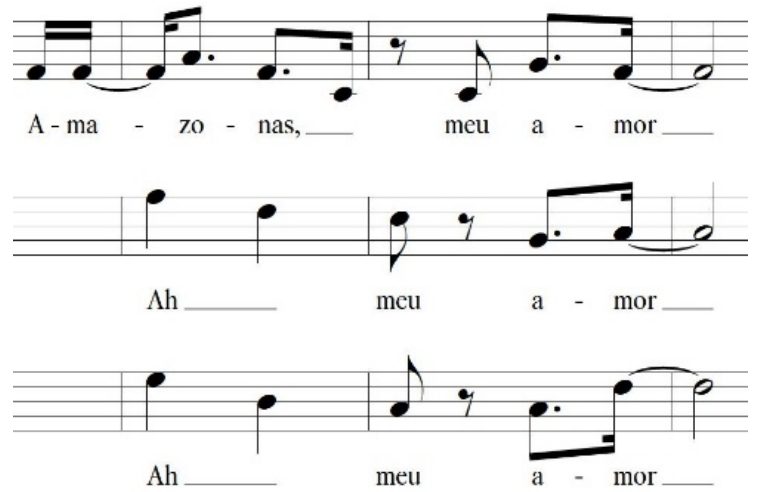

Figura 26 - Compasso 247 e 248 - Fonte: elaboração dos autores.

\subsubsection{CODA C. $250-273$}

A coda é gerada a partir de material da canção original apresentada na primeira seção, até então inédito na Suíte.

O tenor inicía a melodia ao que as vozes superiores a desenvolvem contrapontisticamente em fugatto sobre um baixo pedal que demarca as fundamentais a cada mudança de acorde.

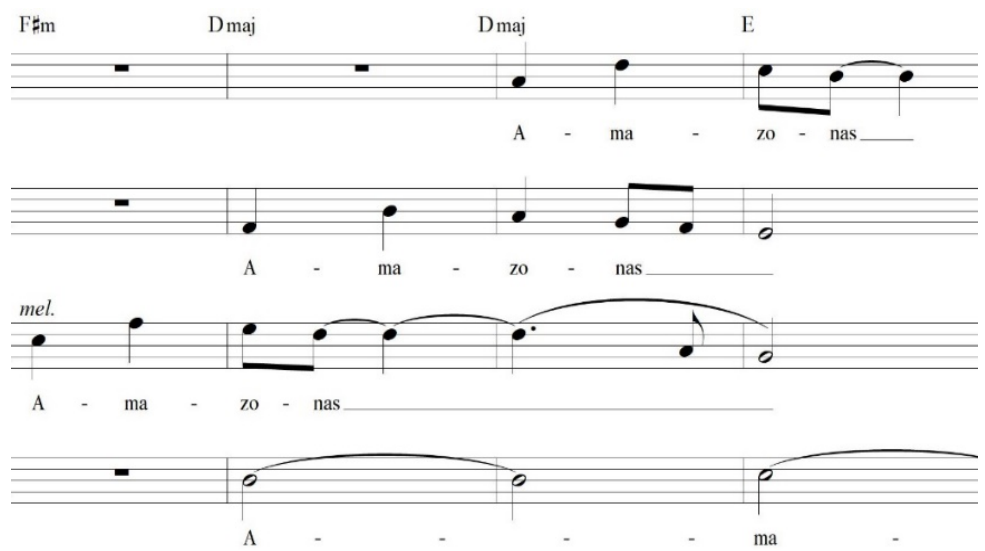

Figura 27 - Compasso 250 ao 253 - Fonte: elaboração dos autores.

No compasso 255 , soprano e contralto desenvolvem uma melodia melismática em movimento paralelo.

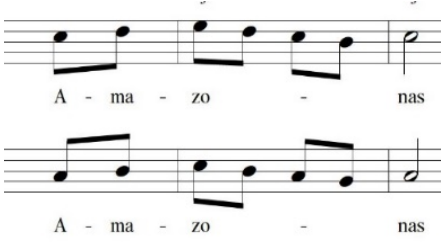

Figura 28 - Compasso 255 ao 257 - Fonte: elaboração dos autores. 


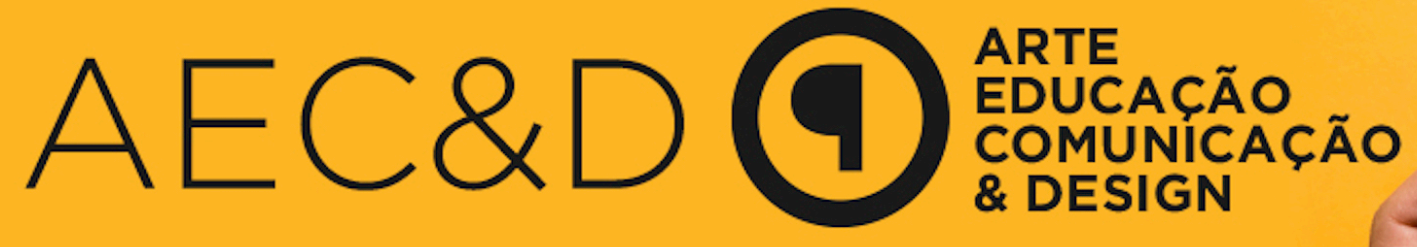

Em seguida o tenor realiza uma antecipação da melodia principal que passa ficar a cargo do contralto. Os homens em diálogo, respondem e juntam-se às vozes femininas no c. 259 direcionando a harmonia à dominante $\mathrm{C} \# 7$. O soprano mais uma vez executa um melisma descendente após abrir vozes com o contralto, repousando sobre a sensível da tônica.

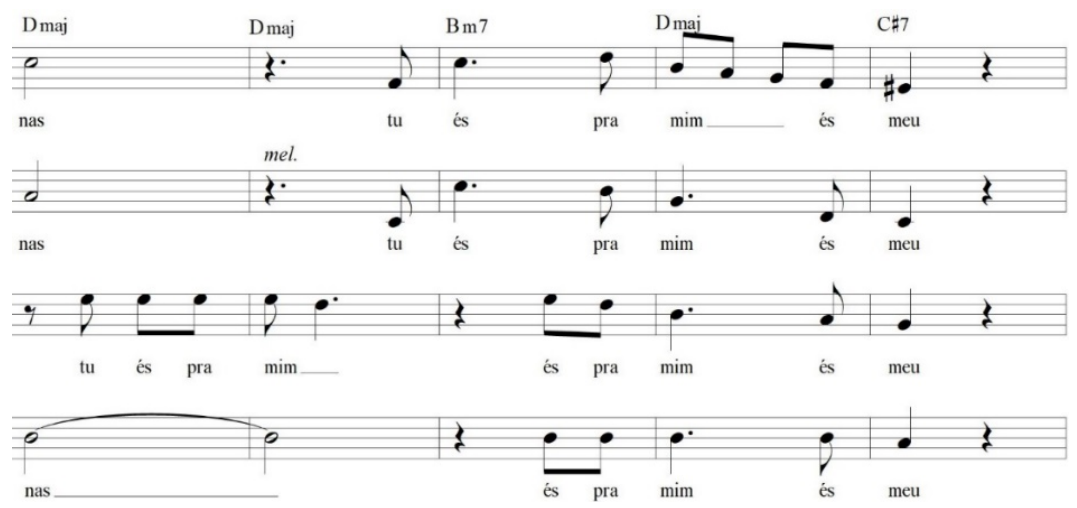

Figura 29 - Compasso 257 ao 261 - Fonte: elaboração dos autores.

Em meio ao silêncio, tenor retoma a melodia principal. Com vista a prolongar por um pouco mais o discurso musical, as vozes movimentam a harmonia em direção ao grau subdominante $(\mathrm{Bm})$, ao invés de completar a cadência sobre a tônica. Após isto, da subdominante passa-se rapidamente pela tônica, seguindo em direção ao $\mathrm{V}$ grau menor $(\mathrm{C \# m})$ no qual, através do contralto, suger uma 11 a a ser logo resolvida sobre a 3a menor do acorde. Na continuação temos uma sequência de inverções sobre um acorde diminuto direcionando as tensões a buscarem resolução sobre a tônica, que surge logo em seguida, mas ainda não forma totalmente conclusiva, tendo seu baixo na 5a j.

Tem-se, então, os últimos quatro compassos. As vozes chegam à dominante com a 4 a suspensa no contralto, resolvida ainda no mesmo compasso, transformando o acorde em C\#7. As vozes inferiores movem-se, então, a formar o acorde de tônica F\#m, enquanto o soprano mantém sustentada a 7ạ de C\# do compasso anterior, tornando-se agora 4al s sobre o acorde de F\# harmonizado pelas outras vozes. No compasso seguinte, o tenor movimenta-se do V ao VI grau menor de F\#, formando um acorde de $\mathrm{Bm} / \mathrm{F \#}$ ao que na segunda metade do tempo, a 4a suspensa no soprano, movimenta-se à $2^{a}$ e é resolvida, no compasso final, ascendentemente sobre a terça maior de F\#, finalizando a obra com uma terça de picardia.

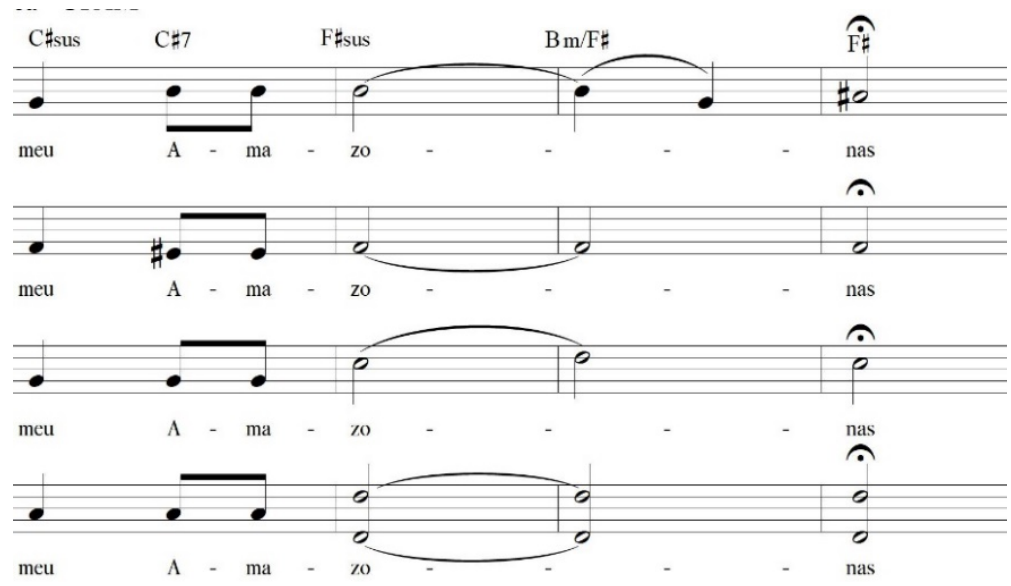

Figura 30 - Compasso 270 ao 273 - Fonte: elaboração dos autores. 


\section{CONCLUSÃo}

No processo de preparação para a composição de um arranjo musical, lan Guest (1996, p. 121) faz uma serie de alertas de indicações ao aspirante a arranjador, sendo um destes pontos o cuidado e atenção em adequar o material de acordo com o grupo em vista a executá-lo, de forma que viabilize de fato a execução sem grandes impecilhos técnicos musicais. De fato isto é algo que, no dia-a-dia de um profissional, deve ser sendo levado em consideração, no entanto, há de se considerar também a necessidade de em alguns momentos se praticar a escrita compositiva sem as barreiras que algumas condições reais nos impoem. Foi exatamente o que se buscou ser feito em "Suite Amazônida": não limitar suas possibilidades de composição como tentativa de torná-la de facil execução por qualquer grupo, mas sim, com o foco tão somente no desenvolver da música, construir uma obra bem elaborada de forma a valorizar cada aspecto em seu percursso.

Almada (2000, p. 101) alega que aos poucos o arranjador, de acordo com sua experência e segurança no assunto, começa a tomar as decisões mais acertadas diante do "labirinto de escolhas que é o ato de compor-arranjar", ao nivel de, inclusive, antever os resultados provenientes que cada possivel escolha que venha tomar. As possibilidades no momento da escrita de um arranjo musical são infinitas, sendo limitadas somente pela própria imaginação humana.

\section{REFERÊNCIAS BIBLIOGRÁFICAS}

ALMADA, C. (2000). Arranjo. Campinas: Unicamp.

ASSAYAG, S. (1995). Boi-Bumbá: festas, andanças, luz e pajelança. . Rio de Janeiro: Funarte.

BLATER, A. (1980). Instrumentation/Orchestration. New York: Longman Inc.

FARIAS, J. C. (2005). De Parintins para o mundo ouvir: Na cadência das toadas dos dois bois-bumbás Caprichoso e Garantido. Rio de Janeiro: Litters Ed.

GUEST, I. (1996). Arranjo Método Prático, vol 1. Rio de Janeiro: Lumiar.

GUEST, I. (2006). Harmonia Método Prático, vol 1. Rio de Janeiro: Lumiar.

MEDEIROS, F. P. (2009). O Carinhoso de Cyro Pereira: arranjo ou composição? Dissertação (Mestrado em Processos de Criação Musical), São Paulo. doi:doi:10.11606/D.27.2009.tde-08022010-181717

MONTEIRO, M. Y. (2004). Boi-Bumbá: História, análise fundamental e juizo crítico. Manaus: Edição do autor.

NOGUEIRA, W. (2008). Festas amazônicas: boi-bumbá, cirando e sairé. Manaus: Valer.

PEREIRA, F. V. (2011). As práticas de reelaboração musical. Tese (Doutorado em Musicologia) - Escola de Comunicação e Artes, Universidade de São Paulo, São Paulo. doi:10.11606/T.27.2011.tde24062011-104128

SILVA, M. H. (2005). Boi-Bumbá de Parintins - arte e significado. (Dissertação de Mestrado). Campinas: UNICAMP. 


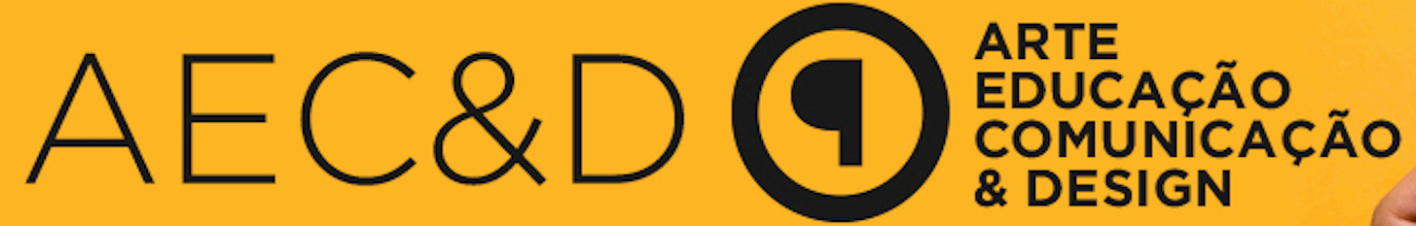

Arranjo coral elaborado como parte integrante do TCC de Lucas Mesquita, sob orientação do prof. Licenciatura em Música - UFAM

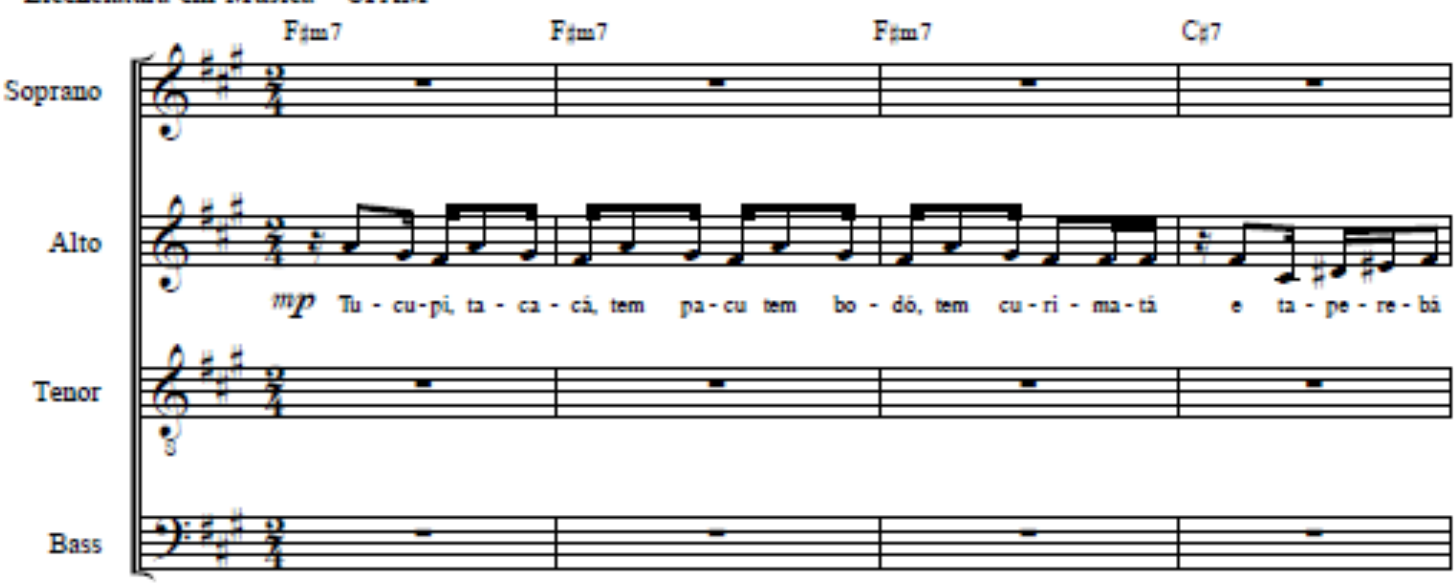

Chico da Silva; Emerson Maia suíte AmazônIDด

"Amazonas Meu Amor"; "Rio Amazonas" Dr. Hermes Coelho Gomes Arr. Lucas Mesquista e Hermes Coelbo, 2018.
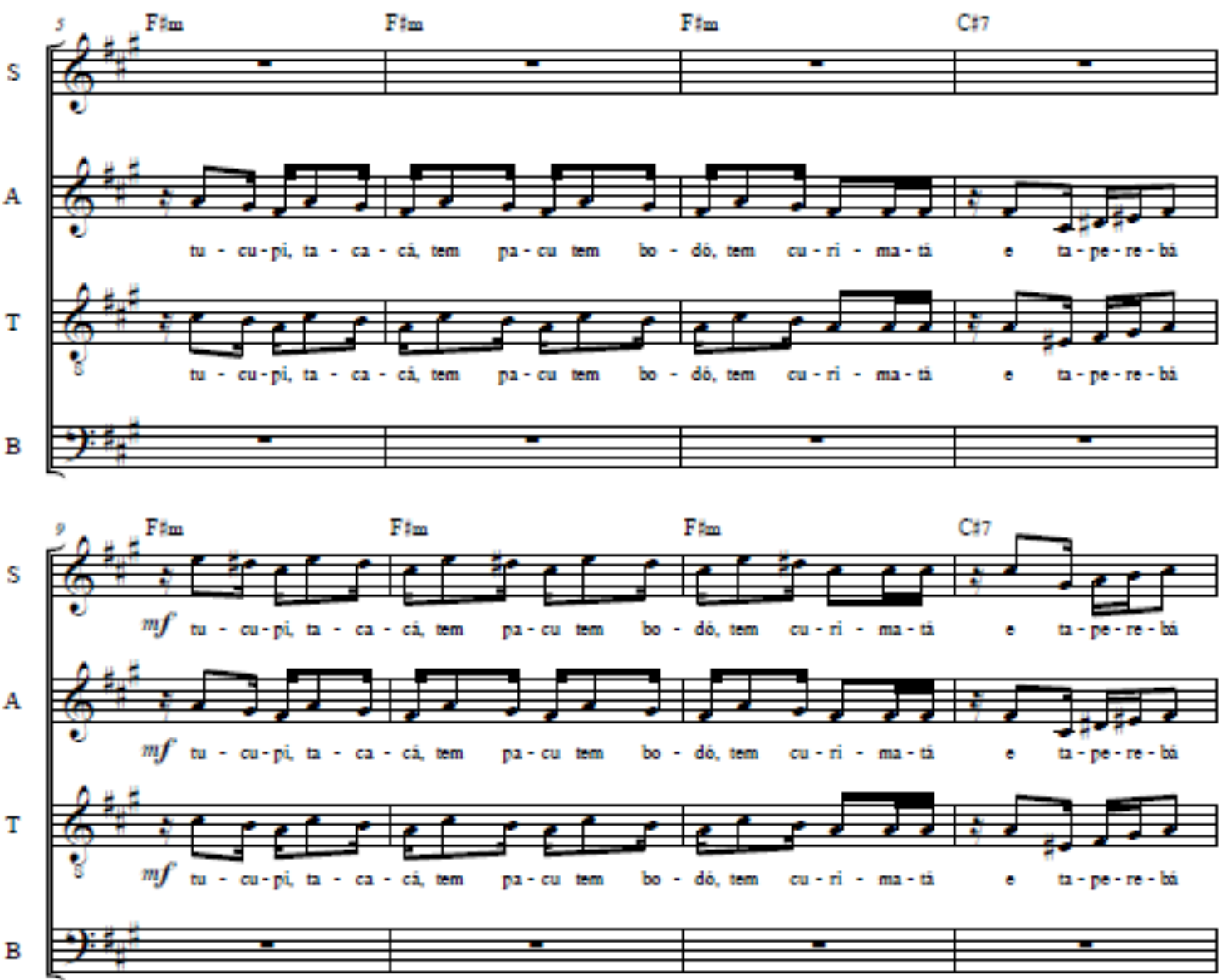

C2018, todos os direitos reservados. Proibido fazer cópias sem autorização. 